\title{
Analisa keberadaan lembaga kesejahteraan sosial anak (LKSA) di Kabupaten Sidoarjo
}

\author{
Analysis of existence of welfare institutions social children (LKSA) \\ in Sidoarjo District
}

\author{
Sutinah \\ Departemen Sosiologi, Fakultas Ilmu Sosial dan Ilmu Politik, Universitas Airlangga \\ E-mail: sutinah@ fisip.unair.ac.id
}

\begin{abstract}
Abstrak
Di Indonesia, diperkirakan jumlah anak terlantar sekitar 3,5 juta jiwa. Ini pun terbatas pada kelompok anak-anak yang yatim piatu dimana dari jumlah itu hanya sedikit di antara mereka yang terjangkau pelayanan sosial. Di Kabupaten Sidoarjo sendiri, jumlah anak terlantar, anak yatim dan anak yatim piatu yang tinggal di berbagai panti diperkirakan mencapai angka ribuan, bahkan lebih, dan tidak mustahil pula angkanya kini terus bertambah karena tekanan kemiskinan dan kondisi perekonomian yang tak kunjung stabil. Kegiatan sebagaimana dilaporkan, selain mencoba melakukan indentifikasi keberadaan LKSA di Kabupaten Sidoarjo dalam mengimplementasikan SNPA, juga sekaligus akan mengkaji dan merumuskan sebuah pendekatan dan model penanganan anak-anak yang terlantar yang ada di panti. Hasil akhir dari kegiatan ini diharapkan akan diperoleh informasi yang dapat digunakan sebagai bahan penyusunan kebijakan dalam mengoptimalkan peran LKSA dalam pemenuhan hak serta perkembangan anak asuhnya. Dengan demikian penelitian Analisa Keberadaan Lembaga Kesejahteraan Anak (LKSA) Di Kabupaten Sidoarjo menjadi penting untuk dilaksanakan. Metode yang digunkan pertama yaitu mengkaji dan menganilisis data sekunder. Kedua melakukan review. Dan ketiga yaitu melakukan penggalian data primer ke lapangan. Hasil studi ini menunjukkan kondisi LKSA di Kabupaten Sidoarjo masih banyak yang belum memenuhi standarisasi yang telah ditetapkan dalam SNPA. Kendala yang dihadapi pengurus LKSA dalam memenuhi standarisasi SNPA, selain berkaitan dengan keterbatasan dana dan SDM, juga karena jumlah anak asuh yang dilayani tidak sebanding dengan kemampuan pendanaan dan SDM yang diimiliki. Kedua, bagi anak-anak asuh panti, situasi problematik yang mereka hadapi terkait dengan kondisi LKSA.
\end{abstract}

Kata kunci: anak, identifikasi, kondisi, panti, sejahtera

\begin{abstract}
In Indonesia, it is estimated that the number of abandoned children is around 3.5 million. This is also limited to the group of orphaned children where only a few of them are reached by social services. In Sidoarjo Regency alone, the number of neglected children, orphans and orphans living in various orphanages is estimated at thousands, even more, and it is also possible that the numbers continue to grow now due to poverty pressures and unstable economic conditions. The activity as reported, besides trying to identify the existence of LKSA in Sidoarjo Regency in implementing SNPA, will also simultaneously study and formulate an approach and model for handling abandoned children in the institution. The end result of this activity is expected to obtain information that can be used as material for policy formulation in optimizing the role of LKSA in fulfilling the rights and development of foster children. Thus the research on Analysis of the Existence of Child Welfare Institutions (Lksa) in Sidoarjo Regency is important to be carried out. The first method used is reviewing and analyzing secondary data. Second do a review. And the third is conducting primary data mining in the field. The first result is that in general the conditions of LKSA in Sidoarjo Regency are still many that do not meet the standards set out in the SNPA. The obstacles faced by the LKSA management in fulfilling the SNPA standardization, in addition to being related to limited funds and human resources, are also because the number of fostered children served is not proportional to the funding and human resource capabilities they possess. Second, for foster children, the problematic situation they face is related to the LKSA conditions.
\end{abstract}

Keywords: child, identification, condition, orphanage, prosperous

\section{Pendahuluan}

Pada tahun 1990 Indonesia telah meratifikasi Konvensi Hak Anak (KHA) melalui Keppres 36/1990 pada tanggal 25 Agustus 1990 di mana substansi inti dari KHA adalah adanya hak asasi yang dimiliki anak dan ada tanggung jawab Negara maupun pemerintah, masyarakat, dan orang tua untuk 
kepentingan terbaik bagi anak agar meningkatnya efektivitas penyelenggaraan perlindungan anak secara optimal. Kemudian KHA dikuatkan dengan terbitnya Undang-Undang Nomor 35 tahun 2014 perubahan atas Undang-Undang No 23 tahun 2003 tentang Perlindungan Anak yang mengatur tentang Hak dan Kewajiban Anak, serta kewajiban dan tanggug jawab negara, pemerintah, masyarakat, keluarga, dan orang tua. Di samping itu juga diatur tentang kuasa asuh, perwalian, pengasuhan dan pengangkatan anak, serta penyelenggaraan perlindungan (Mulia, 2013).

Masa kanak-kanak menjadi tiga tahap yaitu masa bayi umur 0-menjelang 2 tahun yaitu masa dimana keadaan anak masih lemah dan kehidupannya sangat tergantung kepada orang tua, terutama pada ibu, kemudian masa kanak-kanak pertama yaitu umur 2-5 tahun dan masa kanak-kanak terakhir yaitu berumur 5-12 tahun (Supramono, 2005).

Anak yatim, anak yatim piatu dan anak-anak terlantar sesungguhnya adalah anak-anak yang termasuk kategori anak rawan atau anak-anak membutuhkan perlindungan khusus (children in need of special protection). Dalam Buku Pedoman Pembinaan Anak Terlantar yang dikeluarkan Dinas Sosial Propinsi Jawa Timur (2001) disebutkan bahwa yang disebut anak terlantar adalah anak yang karena suatu sebab tidak dapat terpenuhi kebutuhan dasarnya dengan wajar, baik secara rohani, jasmani mau pun sosial.

Panti Asuhan adalah lembaga kesejahteraan sosial yang memiliki tanggung jawab untuk memberikan pelayanan kesejahteraan sosial kepada anak terlantar, memberikan pelayanan pengganti atau perwalian anak dalam memenuhi kebutuhan fisik, mental dan sosial pada anak asuh sehingga memperoleh kesempatan yang luas, tepat dan memadai bagi perkembangan kepribadiannya (Sidiq, 2017).

Panti sosial adalah suatu lembaga kesejahteraan sosial yang mempunyai tanggung jawab untuk memberikan layanan kesejahteraan sosial kepada anak terlantar dengan melaksanakan penyantunan dan pengentasan anak terlantar, memberikan pelayanan pengganti orang tua/wali anak dan memenuhi kebutuhan fisik, mental dan sosial pada anak asuh sehingga memperoleh kesempatan yang luas, tepat dan memadai bagi perkembangan keperibadiannya sesuai dengan yang diharapkan sebagai generasi penerus cita-cita bangsa dan sebagai insanyang akan turut serta aktif didalam bidang pembangunan nasional (Fathul, 2015).

Alternatif terakhir apabila seorang anak terlantar karena ketidak-mampuan orang tua dalam mengasuh adalah anak di serahkan ke pelayanan sosial melalui panti. Panti mendorong masyarakat untuk ikut serta untuk membantu menangani anak terlantar melalui program perwalian. Di mana anak terlantar dimungkinkan mendapatkan orang tua ataupun keluarga pengganti yang membantu kelangsungan hidup dan tumbuh kembangnya (Ali, 1986).

Di wilayah mana pun, banyak bukti memperlihatkan bahwa anak-anak selalu merupakan kelompok yang paling rentan terhadap berbagai proses perubahan sosial-politik dan ekonomi yang tengah berlangsung. Di berbagai komunitas, anak-anak seringkali menjadi korban pertama dan menderita, serta terpaksa terhambat proses tumbuh-kembang mereka secara wajar karena ketidakmampuan orang tua, masyarakat dan pemerintah untuk memberikan pelayanan sosial yang terbaik bagi anak-anak.

Bagi masyarakat dan keluarga miskin, terlebih lagi bagi anak-anak yang terkategori rawan dan terlantar, situasi krisis ekonomi yang terjadi dua dekade silam adalah awal-mula dari timbulnya berbagai masalah yang sepertinya makin mustahil untuk dipecahkan secara instan. Situasi krisis ekonomi bukan cuma melahirkan kondisi kemiskinan yang makin parah, tetapi juga menyebabkan situasi menjadi teramat sulit. Krisis ekonomi, dan kondisi perekonomian nasional yang tak kunjung pulih meski bukan merupakan satu-satunya faktor pencipta anak-anak rawan, tetapi bagaimana pun krisis yang tak kunjung usai menyebabkan daya tahan, perhatian, dan kehidupan anak-anak menjadi makin marginal, khususnya bagi anak-anak yang sejak awal tergolong anak-anak rawan dan terlantar.

Seorang anak dikatakan terlantar, ketika anak tersebut tidak memiliki hak tumbuh dan hak berkembbang secara wajar, tidak memiliki pendidikan yang layak, tidak memperoleh pelayanan 
kesehatan yang memadai. Penyebab dari terlantarnya anka bisa disebabkan oeleh kelalaian, orang tua yang kurang faham akan kondisi anak, dan kelahiran yang tidak dikehendaki (Suyanto, 2013).

Di Indonesia, diperkirakan jumlah anak terlantar sekitar 3,5 juta jiwa. Ini pun terbatas pada kelompok anak-anak yang yatim piatu dimana dari jumlah itu hanya sedikit di antara mereka yang terjangkau pelayanan sosial (Irwanto, 1998). Di tahun 2015 ini, bisa dipastikan jumlah anak terlantar yang ada akan lebih banyak lagi, karena tekanan kemiskinan yang merambah ke berbagai wilayah. Di Kabupaten Sidoarjo sendiri, jumlah anak terlantar, anak yatim dan anak yatim piatu yang tinggal di berbagai panti diperkirakan mencapai angka ribuan, bahkan lebih, dan tidak mustahil pula angkanya kini terus bertambah karena tekanan kemiskinan dan kondisi perekonomian yang tak kunjung stabil.

Sebagian anak yang terlantar, terutama anak yatim atau anak yatim piatu, selama ini mereka biasanya tinggal di panti-panti dan hidup di bawah asuhan pengelola panti. Bagi anak-anak yang terlantar yang tinggal di panti-panti, apa yang menjadi kebutuhan mereka sebetulnya memang bukan sekadar memperoleh perlindungan dan terpenuhi kebutuhan dasarnya, tetapi yang tak kalah penting adalah bagaimana mereka dapat memperoleh jaminan dan kesempatan untuk dapat tumbuh-kembang secara wajar. Sekali pun banyak warga masyarakat akan bersimpati dan peduli kepada nasib anak-anak yang terlantar, tetapi dalam kenyataan mereka tetap saja rawan diperlakukan salah, menjadi korban eksploitasi oleh pihak-pihak tertentu yang ingin memanfaatkan situasi, dan diterlantarkan, atau bahkan dilanggar haknya.

Anak terlantar pada dasarnya adalah sebuah istilah untuk menggambarkan kelompok anak-anak yang karena situasi, kondisi dan tekanan-tekanan kultur maupun struktur menyebabkan mereka belum atau tidak terpenuhi hak-haknya dan bahkan acapkali dilanggar hak-haknya. (Kemensos, 2014) Sedangkan perlindungan anak adalah segala kegiatan untuk menjamin dan meindungi anak dan hak-haknya agar dapat hidup tumbuh berkembang dan berpartisipasi secara optimal sesuai dengan harkat dan martabat kemanusiaan serta dapat perlindunga dari kekerasan dan diskriminasi (Kominfo, 2011) Jika anak di rawat oranng tua dalam kualitas hubungan, kelekatan yang aman memainkan peranan yang penting dalam perkembangan moral anak (Santrock, 2007).

Di atas kertas, panti asuhan memang merupakan suatu lembaga yang sangat populer untuk membentuk perkembangan anak-anak yang tidak memiliki keluarga ataupun yang tidak tinggal bersama dengan keluarga. Anak-anak panti asuhan biasanya akan diasuh oleh pengasuh yang menggantikan peran orang tua dalam mengasuh, menjaga dan memberikan bimbingan kepada anak agar anak tersebut menjadi manusia dewasa yang berguna dan bertanggung jawab atas dirinya dan terhadap masyarakat di kemudian hari. Berdasarkan data yang dihimpun oleh organisasi sosial Save the Children, Indonesia menempati urutan kedua sebagai negara dengan jumlah panti asuhan anak terbanyak di dunia. Lebih dari 8.000 panti asuhan anak yang terdaftar di lembaga sosial tersebar di seluruh Indonesia, jumlah tersebut akan mengalami peningkatan karena masih banyak panti asuhan anak yang belum terdaftar. Jumlahnya diperkirakan mencapai 15.000 lebih panti asuhan yang dapat menempatkan Indonesia melonjak ke urutan pertama sebagai negara dengan jumlah panti asuhan terbanyak di dunia (http://news.unpad.ac.id/?p=37106, akses tanggal 15 Januari 2015).

Dalam perkembangannya dewasa ini, peran dan fungsi panti asuhan harus diakui mulai dipertanyakan kefektifannya dalam pengasuhan anak yang tidak memiliki keluarga. Negara-negara pencetus konsep panti asuhan, seperti Amerika Serikat dan negara-negara Eropa pada saat ini sudah meninggalkan konsep panti asuhan. Hal ini terkait dengan tidak efektifnya panti asuhan dalam memberikan hak dasar setiap anak, yaitu mendapatkan kasih sayang (http://news.unpad.ac.id/?p=37106, akses tanggal 15 Januari 2015).

Pada umumnya sebuah panti asuhan hanya mempunyai seorang pengasuh, padahal jumlah anak asuh seringkali lebih dari sepuluh anak. Akibatnya kasih sayang yang diberikan pengasuh kepada anak asuhnya tentunya sangat kurang. Hasil penelitian yang dilakukan oleh Kementerian Sosial dan Save the Children yang didukung oleh UNICEF pada tahun 2006 dan 2007 makin memperkuat argumen tersebut. Penelitian yang dilakukan di enam provinsi tersebut bertujuan untuk menyediakan gambaran 
yang komprehensif tentang kualitas pengasuhan di Panti Sosial Asuhan Anak (PSAA) di Indonesia. Beberapa temuan inti dari penelitian tersebut adalah panti Sosial Asuhan Anak lebih berfungsi sebagai lembaga yang menyediakan akses pendidikan kepada anak daripada sebagai lembaga alternatif terakhir pengasuhan anak yang tidak dapat diasuh oleh orangtua atau keluarganya. Kemudian, anakanak yang tinggal di panti umumnya (90\%) masih memiliki kedua orang tua dan dikirim ke panti dengan alasan utama untuk melanjutkan pendidikan. Berdasarkan tujuan panti ke arah pendidikan, anak-anak harus tinggal lama di panti sampai lulus SLTA dan harus mengikuti pembinaan daripada pengasuhan yang seharusnya mereka terima. Pengurus panti tidak memiliki pengetahuan memadai tentang situasi anak yang seharusnya diasuh di dalam panti, dan pengasuhan yang idealnya diterima anak.

Pada tahun 2007 juga dilakukan penelitian mengenai kehidupan anak di panti asuhan yang dilakukan oleh anak-anak penghuni panti. Sebanyak 60 anak dari enam panti di Kalimantan dan Barat dan Maluku menjadi objek penelitian. Penelitian ini memberikan gambaran tentang kehidupan keseharian mereka di panti dan di luar panti. Umumnya anak-anak mencemaskan kondisi setelah mereka menyelesaikan SLTA. Keterbatasan dukungan pada saat mereka berada di panti, ketidakdekatan dengan keluarga, dan kehilangan teman di lingkungan rumah serta panti saat harus ke luar panti, membuat anak-anak bingung dan cemas.

Berdasarkan hasil kedua penelitian tersebut dan untuk memposisikan panti secara tepat sebagai institusi yang melaksanakan fungsi pengasuhan, nama Panti Sosial Asuhan Anak dirubah menjadi Lembaga Kesejahteraan Sosial Anak. Dalam Standar Nasional Pengasuhan Anak (SNPA), semua lembaga yang menjalankan fungsi pengasuhan anak, apapun namanya disebut sebagai Lembaga Kesejahteraan Sosial Anak yang disingkat dengan LKSA. Perubahan kebijakan khususnya berkaitan dengan aturan penyelenggaraan pelayanan oleh Lembaga Kesejahteraan Sosial Anak dan berbagai sub sistem lainnya, seperti peran Dinas Sosial/Instansi Sosial, peran pekerja sosial dan masyarakat dalam mendukung pelayanan Lembaga Kesejahteraan Sosial Anak perlu dilakukan. Hal tersebut merupakan dasar yang sangat strategis bagi upaya pelaksanaaan pengasuhan dan perlindungan bagi anak-anak yang berada di luar pengasuhan keluarga.

Perundang-undangan nasional, baik Undang-Undang Nomor 4 Tahun 1979 tentang Kesejahteraan Anak dan Undang-Undang Nomor 23 Tahun 2002 tentang Perlindungan Anak yang kemudian disempurnakan dalam Undang-Undang Nomor 35 Tahun 2014, telah menyatakan pentingnya pengasuhan anak oleh orang tua dan keluarga, akan tetapi hal tersebut belum sepenuhnya terpenuhi pada tataran implementasi. Meningkatnya jumlah panti dari tahun ke tahun menunjukkan sangat diperlukannya upaya penyadaran pada berbagai kalangan agar mengedepankan pendekatan berbasis keluarga daripada pendekatan institusional dalam pengasuhan anak. Sebagai langkah bersama peningkatan pelayanan kesejahteraan sosial anak, telah dibuat Standar Nasional Pengasuhan Anak (SNPA) untuk LKSA yang tertuang dalam Peraturan Menteri Sosial Republik Indonesia Nomor: 30/HUK/2011. Walaupun demikian, pendidikan utama anak berada di tengah-tengah keluarga. SNPA berisikan norma, standar, prosedur, dan kriteria dalam pelaksanaan pengasuhan anak yang digunakan sebagai pedoman bagi lembaga kesejahteraan sosial anak dalam menyelenggarakan pengasuhan anak. Standar Nasional Pengasuhan Anak terdiri dari prinsip-prinsip pengasuhan alternatif, penentuan respon yang tepat bagi anak, pelayanan pengasuhan dan kelembagaan, yang pengaturannya ditetapkan dalam Lampiran Peraturan Menteri Sosial Republik Indonesia Nomor: 30/HUK/2011 ini.

Keberadaan panti asuhan di Kabupaten Sidoarjo menurut informasi yang diperoleh dari Dinas Sosial dan Tenaga Kerja Kabupaten Sidoarjo ditengarai mengalami permasalahan yang sama dengan panti asuhan pada umumnya. Berdasarkan data yang ada, terdapat 99 lembaga yang mengantongi ijin sebagai LKSA. Namun masih ada ketidaksesuaian antara ijin dan kegiatan yang dilakukan lembaga tersebut. Dari sejumlah LKSA yang tersebar di Kabupaten Sidoarjo dengan jumlah anak asuh mencapai 3.000 anak, diduga sebagian besar belum memenuhi ketentuan SNPA. Keberadaan SNPA yang belum diimplementasikan oleh LKSA di Kabupaten Sidoarjo tentunya perlu mendapat perhatian yang serius dari berbagai pihak, khususnya pemerintah. Kondisi LKSA yang belum memenuhi SNPA 
tentunya akan memberikan dampak yang cukup serius bagi perkembangan anak asuh sebagai akibat dari belum terpenuhinya hak-hak mereka dalam LKSA.

Dari segi penampakan fisik, perlakuan dan ancaman yang dihadapi anak-anak yang tinggal di panti asuhan barangkali memang tidak sedramatis ketika kita mendengar atau menyaksikan anak-anak yang menjadi korban tindak kekerasan, seperti anak perempuan korban perkosaan atau anak-anak yang menjadi korban tindak kekerasan: terluka secara fisik, atau bahkan dianiaya hingga tewas. Tetapi, dari segi sosial dan psikologis, ancaman yang dihadapi anak-anak terlantar sesungguhnya tidaklah kalah berbahaya. Di tingkat individu, anak-anak yang sejak dini terbiasa diterlantarkan, maka jangan heran jika mereka kemudian tumbuh inferior, rendah diri atau sebaliknya menjadi agresif dan nakal untuk menarik perhatian orang-orang di sekitarnya. Bahkan, tidak mustahil anak-anak yang diterlantarkan, kemudian terlibat dalam tindak kriminal karena salah asuhan dan salah pergaulan.

Bagi anak-anak terlantar yang tinggal di panti-panti asuhan, untuk sebagian persoalan mereka kini mungkin telah diatasi dengan pendekatan pengasuhan, pemberian bantuan dan pemberian perlindungan. Tetapi, bagi anak-anak terlantar yang tinggal di luar panti, boleh dikata sampai saat ini masih belum terumuskan pola pendekatan macam apa yang tepat dan efektif untuk dikembangkan. Sekali pun di Kabupaten Sidoarjo data yang pasti tentang jumlahnya masih belum ada, namun demikian diduga di berbagai komunitas, terutama komunitas masyarakat miskin, jumlah anak-anak yang terlantar ini relatif besar. Akibat ketidakmengertian, salah pengasuhan, dan ketidakmampuan keluarga-keluarga yang miskin dan rentan secara sosial, sadar atau tidak, mereka dengan sengaja atau terpaksa kemudian mengorbankan kebutuhan dasar anak-anaknya, sehingga terjadilah berbagai kasus anak yang diterlantarkan.

Kegiatan sebagaimana dilaporkan, selain mencoba melakukan indentifikasi keberadaan LKSA di Kabupaten Sidoarjo dalam mengimplementasikan SNPA, juga sekaligus akan mengkaji dan merumuskan sebuah pendekatan dan model penanganan anak-anak yang terlantar yang ada di panti. Hasil akhir dari kegiatan ini diharapkan akan diperoleh informasi yang dapat digunakan sebagai bahan penyusunan kebijakan dalam mengoptimalkan peran LKSA dalam pemenuhan hak serta perkembangan anak asuhnya. Dengan demikian penelitian Analisa Keberadaan Lembaga Kesejahteraan Anak (Lksa) Di Kabupaten Sidoarjo menjadi penting untuk dilaksanakan.

\section{Metode Penelitian}

Studi ini pada dasarnya selain bermaksud mengidentifikasi situasi problematik yang tengah dihadapi anak-anak terlantar yang ada di lingkungan panti asuhan, juga sekaligus mencoba mengkaji kinerja panti asuhan dan berbagai problema yang mereka hadapi dalam menjalankan perannya sebagai lembaga yang bertanggungjawab terhadap pengasuhan dan perlindungan anak. Secara garis besar, metode dan tahapan yang dilakukan dalam kegiatan ini adalah sebagai berikut: Pertama, mengkaji dan menganilisis data sekunder tentang anak terlantar dan panti asuhan yang ada di Kabupaten Sidoarjo. Data sekunder yang dibutuhkan dicari dari BPS, Dinas Sosial dan Pemberdayaan Perempuan, surveisurvei lokal, dan data dari berbagai Perguruan Tinggi dan Lembaga Penelitian lainnya. Uraian tentang kondisi umum ini penting untuk mengetahui peta makro permasalahan anak terlantar, khususnya mereka yang tinggal di panti asuhan.

Kedua, melakukan review terhadap hasil-hasil studi mengenai anak terlantar dan panti asuhan pada umumnya. Review terhadap berbagai hasil penelitian tentang anak terlantar dan panti asuhan ini penting dilakukan dalam rangka menyusun kerangka acuan dan analisis terhadap temuan data yang diperoleh di lapangan. Ketiga, melakukan penggalian data primer ke lapangan untuk memperoleh gambaran yang valid dan akurat mengenai kondisi panti asuhan di Kabupaten Sidoarjo. Secara keseluruhan, jumlah panti yang diteliti, menurut rencana sebanyak 100 lembaga sebagaimana terdata dan tersebar di berbagai wilayah di Kabupaten Sidoarjo. Tetapi, karena sebagian panti sudah tidak lagi beroperasi, kesibukan pengurus, dan sebagian krena menolak untuk dimonitoring, maka pada akhirnya kegiatan ini hanya berhasil memonitor 86 panti asuhan anak yang ada di Kabupaten Sidoarjo. 


\section{Hasil dan Pembahasan}

Data yang berhasil dikumpulkan, dalam kegiatan ini telah diverifikasi, dan diolah dengan program SPSS. Namun terlebih dahulu dilakukan editing untuk menyaring data yang benar-benar valid. Khusus untuk data kualitatif pengklasifikasian dan pengkategorian data dilakukan oleh tim khusus. Data hasil pendataan yang dilakukan di lapangan ini sudah barang tentu tidak akan ditampilkan mentah-mentah, tetapi diolah dan ditampilkan data-data dalam bentuk yang ringkas dengan harapan agar lebih mudah dipahami pembaca dan memperjelas analisis. Tabel 1 menunjukkan panti yang gagal dimonitoring.

Tabel 1.

Panti yang gagal dimonitoring

\begin{tabular}{|c|c|c|}
\hline Nama Panti & Alamat & Uraian \\
\hline Al-Fitriyah & $\begin{array}{c}\text { Desa Kajartengguli } \\
\text { 2/1 Kecamatan } \\
\text { Prambon }\end{array}$ & $\begin{array}{c}\text { Panti Asuhan Al-Fitriyah yang berlokasi di } \\
\text { Desa Kajartengguli } 2 / 1 \text { Kecamatan } \\
\text { Prambon sudah tidak aktif dan dapat } \\
\text { dikatakan sudah tidak ada. Menurut hasil } \\
\text { survey yang dilakukan oleh peneliti, panti } \\
\text { tersebut sudah vakum dan sekarang ini } \\
\text { hanya aktif sebagai Taman Pendidikan } \\
\text { Qur'an (TPQ) yang mendidik anak-anak } \\
\text { dalam bidang agama khususnya membaca } \\
\text { Al-Qur'an. } \\
\text { Nomor kontak yang bisa dihubungi: } \\
\text { 081230444797 (Bapak Junaidi) }\end{array}$ \\
\hline Al-Chusnaini & $\begin{array}{c}\text { JI Raya Sukodono } \\
\text { RT 15/03 } \\
\text { Kloposepuluh } \\
\text { Sukodono }\end{array}$ & $\begin{array}{l}\text { Para pengurus terlalu sibuk untuk dapat } \\
\text { ditemui, sehingga peneliti beberapa kali } \\
\text { berusaha menghubungi dan menemui } \\
\text { pengurus selalu saja mengalami kegagalan. } \\
\text { Terlebih lagi beberapa waktu yang lalu } \\
\text { pemilik dari Panti Asuhan tersebut } \\
\text { meninggal dunia sehingga menyebabkan } \\
\text { semakin susahnya menghubungi pengurus } \\
\text { yang bersedia diwawancarai }\end{array}$ \\
\hline $\begin{array}{l}\text { Riyadlus Sholihin } \\
\text { (Tidak mau krn } \\
\text { tgl surat } \\
\text { pengantar tdk } \\
\text { valid) }\end{array}$ & $\begin{array}{c}\text { Jl Kol Sugiono No 83- } \\
87 \text { RT 03/11 } \\
\text { Kureksari Waru }\end{array}$ & $\begin{array}{l}\text { Pengurus Panti tidak mau diwawacarai } \\
\text { dikarenakan surat yang kami perlihatkan } \\
\text { dan tujukan kepada panti mengalami } \\
\text { kadaluarsa pada tanggal MONEVnya, } \\
\text { sehingga dirasakan oleh pengurus panti } \\
\text { bahwa surat tersebut tidak valid. }\end{array}$ \\
\hline $\begin{array}{l}\text { YS Sosial Al- } \\
\text { Hafizh }\end{array}$ & $\begin{array}{c}\text { Jl Raya Suko No } 60 \\
\text { Sda }\end{array}$ & $\begin{array}{l}\text { Yayasan sosial ini tidak berkaitan dengan } \\
\text { LKSA dikarenakan yayasan ini lebih } \\
\text { berfokus kepada orang-orang yang } \\
\text { mengalami keterbelakangan mental, serta } \\
\text { dilapangan tidak ditemukan adanya anak- } \\
\text { anak di tempat tersebut, para penghuni } \\
\text { atau pasien nya berusia di atas } 25 \text { tahun. }\end{array}$ \\
\hline $\begin{array}{c}\text { YS Pondok } \\
\text { Sosial Yatim } \\
\text { Piatu Fakir Miskin }\end{array}$ & $\begin{array}{c}\text { JI Masjid Nurul Huda } \\
\text { RT } 05 \text { RW } 01 \\
\text { Sarirogo Sda }\end{array}$ & $\begin{array}{l}\text { Yayasan sosial ini tidak dapat ditemukan } \\
\text { dilapangan, berdasarkan informasi dari } \\
\text { warga setempat bahwa tidak ada yayasan } \\
\text { tersebut diwilayah mereka. Ada pun } \\
\text { beberapa warga hanya sekedar pernah } \\
\text { menderngar mengenai yayasan tersebut, } \\
\text { namun dikatakan bahwa yayasan tersebut } \\
\text { tidak jelas kegiatan maupun } \\
\text { keberadaannya, sehingga diragukan untuk } \\
\text { ada tidaknya oleh warga setempat. Peneliti } \\
\text { juga telah melakukan survey lokasi dan } \\
\text { tidak ditemukan yayasan tersebut, tidak }\end{array}$ \\
\hline
\end{tabular}




\begin{tabular}{|c|c|c|}
\hline & & $\begin{array}{c}\text { adanya plang nama yayasan maupun } \\
\text { informasi dari warga setempat. }\end{array}$ \\
\hline $\begin{array}{l}\text { PA Insan } \\
\text { Cendekia }\end{array}$ & $\begin{array}{l}\text { Perum Pondok Jati } \\
\text { CP } 11\end{array}$ & $\begin{array}{l}\text { Panti Asuhan ini telah berpindah tempat di } \\
\text { Gubeng, daerah Surabaya. alamat yang } \\
\text { terterapun telah berganti penghuni dan } \\
\text { sebagian rumahnya telah kosong dan akan } \\
\text { dijual. }\end{array}$ \\
\hline PA Ulul Albab & $\begin{array}{l}\text { Gebang, Lingkar } \\
\text { Timur, Sidoarjo }\end{array}$ & $\begin{array}{c}\text { Panti Asuhan ini saat kami mensurvey } \\
\text { lokasi ternyata sudah tidak aktif dan tidak } \\
\text { terawatt. Selain itu, menurut salah satu } \\
\text { pengurus dari panti asuhan terdekat } \\
\text { dikatakan bahwa panti asuhan ini telah } \\
\text { tutup atau non-aktif. Menurut beberapa } \\
\text { sumber dari berbagai panti asuhan yang } \\
\text { kami temui bahwa panti asuhan Ulul Albab } \\
\text { di sidoarjo tidak ada, baru ada di Surabaya } \\
\text { dengan nama Ulul Albab Group. }\end{array}$ \\
\hline PA At Taubah & $\begin{array}{c}\text { Jl Lingkar Timur } \\
\text { Wedoro Klurak RT } 10 \\
\text { RW } 02 \text { Candi }\end{array}$ & $\begin{array}{l}\text { Panti Asuhan ini tidak ditemukan dilokasi } \\
\text { alamat tersebut, dan menurut penuturan } \\
\text { dari beberapa warga setempat dikatakan } \\
\text { bahwa panti asuhan ini tidak ada di wilayah } \\
\text { tersebut, tidak pernah diketahui adanya } \\
\text { panti asuhan di wilayah tersebut. Kami } \\
\text { telah mensurvey hingga tingkat RT nya, } \\
\text { namun tidak diketahui keberadaannya. }\end{array}$ \\
\hline PA AL-Ittihat & $\begin{array}{l}\text { Ds. Kalitengah RT } 01 \\
\text { RW } 03 \text { Tanggulangin }\end{array}$ & $\begin{array}{c}\text { Setalah kami mensurvey lokasi panti } \\
\text { asuhan diketahui bahwa panti asuhan } \\
\text { sudah tidak aktif lagi dikarenakan lokasi } \\
\text { panti telah terkena dampak dari lumpur } \\
\text { lapindo sehingga panti asuhan ditutup. } \\
\text { Selain itu, menurut penuturan dari } \\
\text { pengurusa dari panti asuhan terdekat } \\
\text { bahwa panti asuhan tersebut sudah tidak } \\
\text { aktif. }\end{array}$ \\
\hline $\begin{array}{c}\text { PA Al } \\
\text { Mu'awwanah }\end{array}$ & $\begin{array}{l}\text { Ds Kedungrawan RT } \\
05 \text { RW } 03 \text { Krembung }\end{array}$ & $\begin{array}{l}\text { Diketahui bahwa panti asuhan ini sudah } \\
\text { tidak aktif. Menurut penuturan salah satu } \\
\text { pengurus panti di kecamatan yang sama } \\
\text { diketahui bahwa pengurus atau ustad telah } \\
\text { melakukan pelanggaran moral sehingga } \\
\text { panti asuhan menjadi tidak terurus dan } \\
\text { tutup. Selain itu, dari salah satu sumber } \\
\text { yang juga pengurus dari salah satu pant } \\
\text { asuhan terdekat dikatakan bahwa panti } \\
\text { asuhan tersebut sudah tidak aktif, terlihat } \\
\text { dari hilangnya kabar dari panti asuhan } \\
\text { tersebut serta mulai tidak aktifnya pengurus } \\
\text { dalam perkumpulan panti asuhan yang } \\
\text { biasa diadakan. }\end{array}$ \\
\hline $\begin{array}{l}\text { UPT Pelayanan } \\
\text { Sosial Asuhan } \\
\text { Balita }\end{array}$ & $\begin{array}{l}\text { JI W. Munginsidi No } \\
25 \text { Sidoarjo }\end{array}$ & $\begin{array}{c}\text { UPT ini tidak termasuk kedalam system } \\
\text { kerja kabupaten sidoarjo, sehingga enggan } \\
\text { untuk diwawancarai. Salah satu alasan juga } \\
\text { dikarenakan UPT yang langsung dibawa } \\
\text { system kerja provinsi ini memiliki standart } \\
\text { LKSA yang berbeda denan kabupaten } \\
\text { sidoarjo, standart yang digunakan yaitu } \\
\text { standart provinsi. Serta surat ijin yang } \\
\text { diperbolehkan yakni langsung dari provinsi } \\
\text { Jawa Timur. }\end{array}$ \\
\hline $\begin{array}{l}\text { UPT Rehabilitasi } \\
\text { Gelandangan \& }\end{array}$ & $\begin{array}{l}\text { Jl Pahlawan No } 5 \\
\text { Sidoarjo }\end{array}$ & $\begin{array}{l}\text { UPT ini tidak termasuk kedalam system } \\
\text { kerja kabupaten sidoarjo, sehingga enggan }\end{array}$ \\
\hline
\end{tabular}




\begin{tabular}{ccc}
\hline Pengemis & untuk diwawancarai. Salah satu alasan juga & dikarenakan UPT yang langsung dibawa \\
& system kerja provinsi ini memiliki standart \\
& LKSA yang berbeda denan kabupaten \\
& sidoarjo, standart yang digunakan yaitu \\
& standart provinsi. Serta surat ijin yang \\
& diperbolehkan yakni langsung dari provinsi \\
& & Jawa Timur. \\
\hline UPT Lingkungan & Jl Sekolahan No 1 & UPT ini tidak berkaitan dengan LKSA, serta \\
Pondok Sosial & Kutuk Sidokare & saat peneliti berada dilokasi tidak \\
Sidoarjo & Sidoarjo & ditemukan ada nya anak-anak. UPT ini \\
(LIPONSOS) & & hanya penampungan sementara sehingga \\
& jikapun ada anak kecil langsung \\
& dipindahkan di unit yang lainnya. \\
\hline Panti Wredha & JI Malang No 4 & Panti ini tidak berkaitan dengan LKSA \\
Lanudal Juanda & Komple TNI AL & dikarenakan panti ini khusus untuk \\
& Juanda-Sedati & purwirawan. \\
\hline
\end{tabular}

Di akhir laporan, selain dikemukakan kembali ringkasan atau temuan-temuan pokok yang diperoleh tentang kondisi panti asuhan dan situasi problematik yang dihadapi anak terlantar, juga dikemukakan beberapa rekomendasi yang perlu diperhatikan dalam rangka meningkatkan kinerja panti asuhan sesuai Peraturan Menteri Sosial No. 30 Tahun 2011 agar keberadaan anak terlantar tidak makin berkembang ke arah yang dapat merugikan upaya pemenuhan hak-hak anak sesuai UU Perlindungan Anak yang berlaku di Indonesia.

\section{Panti asuhan atau Lembaga Kesejahteraan Sosial Anak (LKSA)}

Panti asuhan atau Lembaga Kesejahteraan Sosial Anak (LKSA) merupakan lembaga yang memiliki misi sosial yakni membentuk perkembangan anak-anak yang tidak memiliki keluarga ataupun yang tidak tinggal bersama dengan keluarga. Peran pengasuh dalam lembaga ini sangat vital dan penting sebagai figur subtitusi atau pengganti peran orang tua dalam mengasuh, menjaga dan memberikan bimbingan kepada anak agar anak menjadi manusia dewasa yang berguna dan bertanggung jawab atas dirinya dan terhadap keluarga, masyarakat, bangsa dan negara di kemudian hari. Mengingat makna penting peran dan fungsi panti/lembaga kesejahteraan sosial anak atau lembaga pengasuhan anak maka visi misi dan seluruh aktivitas yang dilakukan oleh panti atau lembaga kesejahteraan sosial anak seharusnya mendasarkan diri pada pemenuhan hak-hak anak sebagaimana tertuang dalam Konvensi Hak Anak dan Undang-Undang Perlindungan Anak serta berbagai jenis peraturan negara yang mengatur upaya perlindungan terhadap anak

Sebagaimana tertuang dalam dalam Konvensi Hak Anak bahwa pada dasarnya anak yang lahir ke dunia harus terpenuhi hak-hak nya yang meliputi; hak hidup, hak tumbuh kembang, hak perlindungan dan hak partisipasi. Terkait dengan hak hidup maka setiap anak yang lahir ke dunia, dalam kondisi apapun ia berhak untuk hidup, dan tidak ada satu pihak pun yang memiliki wewenang meniadakan hak hidup anak. Sementara itu hak tumbuh kembang mengandung konsekuensi adanya akses kesehatan yang optimal dan pendidikan yang bermutu untuk semua anak. Hak perlindungan adalah semua anak berhak dilindungi dari berbagai jenis kekerasan, eksploitasi dan diskriminasi. Hak partisipasi dalam kehidupan sosial dan budaya diartikan bahwa setiap anak berhak bersosialisasi dengan lingkungan sekitar, bergaul, bermain dan belajar dengan teman sebaya dan menyatakan pendapat sesuai dengan usia dan kematangan anak.

Pemenuhan berbagai ragam hak anak tersebut harus diberlakukan bagi semua anak tanpa terkecuali dengan mendasarkan pada prinsip dasar hak anak yakni; non diskriminasi (non discrimination), kepentingan terbaik untuk anak (the best interest of the child), kelangsungan hidup dan perkembangan anak (survival and development), dan memberikan penghargaan terhadap pendapat anak (respect for the views of the child). Untuk kepentingan mengimplementasikan hak-hak anak tersebut maka negara, 
pemerintah, masyarakat, orangtua dan keluarga berkewajiban dan bertanggungjawab mewujudkan tatanan kehidupan yang mampu melindungi dan memenuhi hak-hak anak.

Panti pengasuhan anak yang banyak terdapat di Kabupaten Sidoarjo selama ini merupakan lembaga kesejahteraan sosial anak yang memberikan pelayanan terhadap anak-anak yang diharapkan mampu memberi dukungan bagi anak di dalam keluarga dengan orientasi utama penguatan kapasitas pengasuhan dalam keluarga. Persoalannya adalah apakah layanan yang diberikan oleh panti selama ini telah sesuai dengan standar nasional pengasuhan anak sebagaimana telah ditetapkan dalam Peraturan Menteri Sosial Republik Indonesia Nomor: 30/HUK/2011. Pada pada bagian berikut ini hendak dikemukakan beberapa temuan penting dari hasil kajian lapangan yang dilakukan di pantipanti yang ada di Kabupaten Sidoarjo. Berdasarkan data hasil kegiatan lapangan tersebut, selanjutnya dirumuskan saran/rekomendasi yang diharapkan dapat memberikan kontribusi kontruktif yang dapat digunakan sebagai bahan penyusunan kebijakan dalam mengoptimalkan peran LKSA dalam pemenuhan hak serta perkembangan anak asuh.

Berdasarkan hasil kajian yang dilakukan di berbagai Panti/ Lembaga Kesejahteraan Sosial Anak yang ada Di Kabupaten Sidoarjo selanjutnya dapat dikemukakan beberapa temuan penting antara lain: Pertama, secara umum kondisi LKSA di Kabupaten Sidoarjo masih banyak yang belum memenuhi standarisasi yang telah ditetapkan dalam SNPA. Kendala yang dihadapi pengurus LKSA dalam memenuhi standarisasi SNPA, selain berkaitan dengan keterbatasan dana dan SDM, juga karena jumlah anak asuh yang dilayani tidak sebanding dengan kemampuan pendanaan dan SDM yang diimiliki. Kedua, bagi anak-anak asuh panti, situasi problematik yang mereka hadapi terkait dengan kondisi LKSA yang belum memadai adalah berusaha beradaptasi dengan situasi dan kondisi yang ada. Meski pun kondisi panti acapkali tidak sesuai dengan standarisasi yang telah ditetapkan, tetapi anakanak asuh yang ada umumnya tidak mempermasalahkan.

Secara lebih rinci, temuan hasil kajian yang dilakukan di lapangan adalah sebagai berikut: Pada umumnya panti/lembaga kesejahteraan sosial anak yang ada di Kabupaten Sidoarjo memiliki status lahan dan bangunan milki sendiri. Artinya pihak panti memiliki hak sepenuhnya atas tanah dan bangunan yang mereka tempati dan manfaatkan untuk melakukan aktivitas pengasuhan anak-anak. Di samping seluruh panti yang ada di Kabupaten Sidoarjo juga telah memiliki akte pendirian. Identitas panti sangat jelas karena sudah terdaftar pada lembaga pemerintah atau ditandatangani oleh pihak atau lembaga yang berwenang. Hal ini terlihat dari mayoritas panti $(90,7 \%)$ telah berstatus terdaftar di Dinsosnaker Sidoarjo bahkan sebanyak 60,46\% panti yang ada juga telah terdaftar pada Depkumham Sidoarjo. Sementara itu sebanyak $32,56 \%$ panti menyatakan saat ini tengah dalam proses mendaftar dan 7,08\% menyatakan belum terdaftar. Dari hasil kajian lapangan juga ditemukan sebanyak $91,86 \%$ panti menyatakan telah ber NPWP dan hanya sebanyak 8,14\% masih belum memiliki NPWP.

Terkait dengan status operasional panti dari 86 panti yang dikunjungi sebanyak $87,21 \%$ panti menyatakan saat ini status operasionalnya adalah sebagai panti pusat dan hanya sebanyak $12,79 \%$ dengan status operasional cabang. Sampai sejauh ini ditemukan bahwa panti yang ada di Kabupaten Sidoarjo sebagian besar $(98,84 \%)$ telah memiliki AD/ART dan hanya sebanyak $1,16 \%$ yang belum memiliki AD/ART. Apabila memperhatikan bidang kegiatan yang dilakukan panti terlihat bahwa panti yang ada lebih banyak sebagai yayasan sosial $(73,26 \%)$ dibandingkan dengan yayasan pendidikan $(26,74 \%)$. Sedangkan status pendaftaran anak asuh umumnya juga masih berlaku di mana sebanyak $73,26 \%$ panti menyatakan status pendaftaran anak asuh masih berlaku, sementara itu sebanyak $16,28 \%$ menyatakan statusnya masih dalam proses pengurusan ulang dan sebanyak $10.46 \%$ menyatakan status pendaftaran anak asuh sudah tidak berlaku.

Meski selama ini panti memperoleh dana dari berbagai sumber tetapi trend yang terlihat menunjukkan bahwa sumber dana yang terbesar lebih bersifat perseorangan $(63,95 \%)$ daripada dari sumbangan pemerintah $(11,63 \%)$ dan perusahaan $(5,81 \%)$ serta sumbangan pengurus $(6,98 \%)$. Sementara itu dengan sumber pendanaan lebih banyak bersifat perseorangan panti memberikan peluang pada anak asuh untuk memberikan fasilitas jenjang pendidikan mayoritas sampai dengan tingkat SMA sederajat 
(66,28\%). Sementara itu sebanyak 31,40\% panti bersedia memfasilitasi jenjang pendidikan sampai tingkat perguruan tinggi atau sarjana pada anak-anak asuhnya.

Studi ini menemukan anak-anak yang ada di panti terlihat masih cukup banyak anak-anak di panti yang belum memiliki akte kelahiran. Sebanyak $76,70 \%$ panti menyebutkan bahwa sampai saat ini ada sekitar 9 anak kebawah yang tidak memiliki akte kelahiran dan sebanyak $14 \%$ mengaku di panti mereka ada sekitar 10-19 anak yang tidak memiliki akte kelahiran. Pada umumnya panti yang ada di Kabupaten Sidoarjo telah cukup lama berdiri. Mayoritas telah melakukan aktivitas pengasuhan anak lebih dari 11 tahun $(53,5 \%)$ dan jumlah pengurus yang dimiliki oleh panti sebagian besar ternyata tidaklah terlampau banyak yakni hanya sekitar $2-11$ orang $(74,40 \%)$. Relatif sedikitnya jumlah pengurus ternyata juga diikuti oleh sedikitnya jumlah pengasuh panti di mana sebagian besar panti memiliki 4 pengasuh dan dibawahnya (57\%). Sementara itu sebanyak $24,4 \%$ panti mengaku memiliki 5-9 orang pengasuh. Hanya sebanyak 3,5\% panti yang mengaku memiliki pengasuh sebanyak 30 orang atau lebih. Meski kebanyakan panti memiliki jumlah pengasuh yang terbatas tetapi faktanya banyak panti yang memiliki pekerja sosial. Mayoritas panti (86\%) yang ditemui mengaku mereka memiliki 9 orang kebawah pekerja osial yang membantu aktivitas dalam panti. Banyak sedikitnya jumlah pengasuh dan pekerja sosial yang membantu aktivitas panti biasanya juga disesuaikan dengan jumlah anak asuh yang ada di panti. Menurut data yang ada sebanyak 19,8\% panti menyebutkan bahwa anak asuh yang ada di panti sejumlah 60 anak lebih. Sementara itu sebanyak 80,2\% panti mengaku bahwa anak asuh yang mereka layani sebanyak kurang dari 60 anak.

Di tiap panti yang ada di Kabupaten Sidoarjo dilengkapi dengan kamar tidur dan kamar mandi dengan jumlah kamar yang beragam. Sebanyak 48,80\% panti menyatakan satu kamar tidur dihuni 4 anak dan di bawahnya dan sebanyak 34,90\% kamar tidur dihuni untuk 5-9 anak. Sementara itu sebanyak 58,1\% panti memiliki sekitar 4 anak per kamar mandi dan di bawahnya dan sebanyak 25,6\% panti menyatakan satu kamar mandi untuk sekitar 5-9 anak. Banyak sedikitnya jumlah kamar tidur dan kamar mandi sangat ditentukan oleh luas lahan panti. Mayoritas panti yang ada di Sidoarjo ternyata memiliki lahan seluas $60-559 \mathrm{~m} 2(65,1 \%)$ dan sebanyak $34,9 \%$ panti memiliki luas lahan diatas 559 $\mathrm{m} 2$.

Berkaitan dengan fasilitas makan dan pakaian untuk anak dari hasil kajian yang dilakukan ditemukan bahwa pada umumnya panti telah memfasilitasi makan anak asuh sebanyak 3 kali sehari $(76,54 \%)$ dan sebanyak $17,28 \%$ menyatakan memberikan fasilitas makan dan minum secara bebas. Bahkan sebanyak $82,72 \%$ panti mengaku selama ini telah memberikan fasilitas makan tambahan pada anak asuh secara tidak menentu. Di samping fasilitas makanan pokok dalam keseharian panti selama ini juga memenuhi jenis makanan seperti susu, teh, kue dan buah meski dengan intensitas yang sering dan jarang. Sementara itu penyediaan makanan yang paling sering dilakukan oleh panti adalah dengan nasi dan lauk secara bebas $(59,26 \%)$ dan sebanyak $32,1 \%$ menyatakan nasi disediakan secara bebas tetapi untuk lauk pauk dijatah.

Dalam soal menu makanan pengurus panti umumnya sering melakukan diskusi dengan anak $(44,44 \%)$, sementara itu sebanyak 28,4\% menyatakan tidak pernah mendiskusikannya. Ketersediaan fasilitas makan seperti: pring, sendok, garpu dan gelas juga telah banyak disediakan oleh pihak panti. Selain fasilitas makan di panti anak-anak asuh juga telah memperoleh fasilitas pakaian. Mayoritas panti yang ditemui menyatakan bahwa selama ini anak-anak telah memperoleh fasilitas 3 stel pakaian untuk pekaian sehari-hari $(84,88 \%)$ dan sebanyak 2 stel seragam sekolah $(93,02 \%)$ serta 1 stel pakaian batik $(77,91 \%)$. Di samping seragam sekolah dan pakaian sehari-hari, anak-anak di panti selama ini juga telah memperoleh fasilitas pakaian olah raga $(86,04 \%)$ dan pakaian ibadah (sarung/ mukena) untuk anak-anak $(90,7 \%)$ serta sajadah $(91,86 \%)$.

Untuk fasilitas pendidikan sebagian besar panti menyebutkan bahwa selama ini telah memberikan berbagai jenis fasilitas untuk semua anak seperti; buku tulis $(93,03 \%)$, buku paket $(94,19 \%)$, alat tulis (94,19\%), uang saku $(81,39 \%)$ dan uang transportasi untuk anak asuh $(63,95 \%)$. Selain fasilitas pendidikan dalam bentuk buku dan uang saku anak-anak asuh juga telah memperoleh fasilitas terkait dengan ketersediaan guru bimbingan dan pendidikan ketrampilan. Menurut data yang ada sebanyak 
$54,65 \%$ menyatakan bahwa selama ini panti teleh menyediakan guru bimbingan belajar pelajaran dengan memadai dan 34,88 menyampaiakan tidak menyediakan fasilitas tersebut. Sementara untuk pendidikan ketrampilan sebagian besar panti mengaku tidak menyediakan fasilitas tersebut $(46,51 \%)$.

Dalam masalah pemenuhan kesehatan selama ini panti juga telah memberikan fasilitas untuk kebersihan badan maupun ruangan seperti; sabun mandi, sikat gigi, pasta gigi, handuk, dan pembalut untuk semua anak yang tinggal di panti. Selain peralatan untuk kebersihan badan pihak panti juga telah menyediakan alat-alat kebersihan yang lain seperti; sapu, kain pel, cairan pembersih dan sikat. Meski fasilitas untuk kebersihan badan dan ruangan telah disediakan oleh panti tetapi untuk aktivitas pemeriksaan kesehatan rutin untuk anak asuh $(44,19 \%)$ dan kepemilikan kartu jaminan kesehatan untuk anak $(56,98 \%)$ masih belum/tidak dilakukan oleh panti yang ada di Kabupaten Sidoarjo.

Secara umum ketersediaan beberapa jenis sarana dan prasarana yang ada di panti ternyata telah tersedia dan dalam keadaan layak. Sarana dan prasarana dimaksud antara lain: lemari untuk menyimpan dokumen/data anak (83,72\%), fasilitas untuk berkesenian $(66,67 \%)$, fasilitas ruang fasilitas ruang ibadah $(87,65 \%)$, bacaan untuk anak $(56,79 \%)$, fasilitas tempat tidur yang berbeda untuk laki-laki dan perempuan $(82,72 \%)$, fasilitas kamar mandi terpisah yang berbeda untuk laki-laki dan perempuan $(80,25 \%)$, ketersediaan fasilitas kunci kamar mandi $(64,20 \%)$, fasilitas kamar mandi dengan rasio 1:5 (70,37\%), fasilitas kunci kamar tidur (72,83\%), fasilitas obat-obatan standar $(77,78 \%)$, fasilitas pencahayaan kamar tidur anak $(85,18 \% 0$, ketersediaan lemari pakaian di kamar tidur anak $(92,60 \%)$, ketersediaan fasilitas cermin di kamar tidur anak $(79,01 \%)$ dan ketersediaan fasilitas luas kamar tidur 4,5 meter persegi per anak $(56,79 \%)$.

Meski kebanyakan panti yang ada di Kabupaten Sidoarjo telah dilengkapi berbagai jenis fasilitas yang memadai tetapi dari kajian ini ditemukan masih banyaknya panti yang belum dilengkapi fasilitas secara layak. Beberapa fasilitas yang masih tidak tersedia secara layak antara lain; peralatan pemadan kebakaran $(91,36 \%)$, fasilitas bermain untuk anak (53,09\%), fasilitas olahraga (51,85\%), ruang perpustakaan $(51,85 \%)$, ruang pelayanan kesehatan anak $(80,25 \%)$, dan Ketersediaan fasilitas meja belajar di kamar tidur anak $(65,43 \%)$.

Berdasarkan hasil kajian lapangan yang dilakukan ditemukan bahwa sebagian besar panti/ lembaga pengasuhan anak di Kabupaten Sidoarjo selama ini telah melakukan asesmen tentang identitas dan latar belakang anak $(72,09 \%)$ dan asesmen $82,56 \%$ panti menyatakan bahwa mereka telah melakukan asesmen terkait dengan identitas, kompetensi, latar belakang relawan panti $(82,56 \%)$.

Berkaitan dengan aktivitas diskusi regular untuk membicarakan kekerasan terhadap anak-anak, dari data yang ada menunjukkan hanya sebanyak $25,58 \%$ panti atau lembaga pengasuhan anak yang menyatakan melakukan diskusi yang bersifat regular untuk membicarakan kekerasan terhadap anakanak secara rutin. Sementara itu sebanyak $29,07 \%$ menyatakan pernah melakukan diskusi tetapi intensitasnya jarang.

Dari hasil kajian lapangan yang dilakukan ditemukan sebagian besar panti atau lembaga kesejahteraan sosial anak di Kabupaten Sidoarjo ternyata telah melaksanakan kebijakan dan peraturan sebagaimana ditetapkan oleh standar nasional pengasuhan anak dengan baik. Berbagai kebijakan dan peraturan dimaksud antara lain; kesempatan anak beribadah (diungkapkan oleh 100\%), kesempatan anak menjalin komunikasi dengan orang tua dan keluarga baik melalui surat maupun tilpun $(93,83 \%)$, kesempatan anak untuk menerima tilpun pukul 09.00 s.d. 21.00 (77,78\%), kesempatan anak untuk menggunakan tilpun pukul 09.00 s.d. $21.00(74,08 \%)$, memfasilitasi pertemuan bulanan anak dengan ortu/keluarga (66,67\%), kesempatan berkunjung dan bertemu teman $(85,18 \%)$, kesempatan berkunjung dan bertemu guru $(85,18 \%)$, kesempatan anak menyatakan pendapat $(91,36 \%)$, tidak bersikap diskriminatif terhadap anak panti $(87,65 \%)$, penyensoran surat/tilpun untuk anak $(55,56 \%)$, kesempatan anak tidur minimal 8 jam $(82,72 \%)$ dan kesempatan anak memiliki waktu luang 2 jam sehari $(90,12 \%)$. 
Kendati cukup banyak kebijakan dan peraturan terkait dengan pemenuhan hak anak yang telah dilaksanakan dengan baik tetapi terdapat beberapa jenis peraturan yang masih belum atau tidak dilaksanakan. Berbagai jenis peraturan dimaksud antara lain kesempatan anak untuk menggunakan internet pukul 09.00 s.d. 21.00 dengan didampingi pengurus (dikemukakan oleh 37,04\%), kesempatan anak menjalin relasi dengan lawan jenis $(40,74 \%)$ pendidikan reproduksi sehat untuk anak $(40,74 \%)$ dan kewajiban anak piket jaga di hari Sabtu/Minggu/libur (48,15\%).

Terkait dengan fasilitas yang disediakan panti agar anak dapat pulang atau mengungjungi orang tua dan keluarga ternyata tidak seluruh panti menyediakan fasilitas untuk seluruh anak. Untuk beberapa panti memang disediakan fasilitas untuk seluruh anak-anak panti ketika mereka akan mengungjungi orang tua atau keluarga. Tetapi secara persentatif jumlah panti yang menyediakan fasilitas bagi anak ketika akan pulang atau mengunjungi orang tua dan keluarga dan yang tidak menyediakan tidaklah jauh berbeda. Fasilitas untuk kesempatan pulang minimal 2 bulan sekali misalnya, sebanyak 51,85\% menyatakan menyediakan untuk semua anak, tetapi di saat yang sama sebanyak 37,04\% menyatakan tidak pernah menyediakan fasilitas tersebut. Kecenderungan yang hampir sama juga terlihat untuk fasilitas biaya transport di mana sebanyak $54,33 \%$ menyatakan menyediakan fasilitas tersebut tetapi sejumlah 30,86\% menyatakan tidak pernah menyediakan fasilitas biaya trasport. Bahkan untuk fasilitas penjemputan anak setelah mengunjungi orang tua atau keluarga sebanyak 62,96\% menyatakan tidak menyediakan fasilitas tersebut. Kondisi yang sama juga ditemukan terkait dengan fasilitas biaya transport orang tua yang akan berkunjung ke panti di mana sebagian besar panti tidak menyediakan fasilitas tersebut.

Secara administratif panti-panti yang berhasil dikunjungi masih belum dilengkapi dengan nomor induk anak dan nomor induk petugas atau staf. Sebanyak 53,49\% panti yang ditemui menyebutkan bahwa selama ini masih belum atau tidak dilengkapi dengan nomor induk anak. Sementara itu sebanyak 72,09\% panti juga menyatakan tidak memiliki nomor induk petugas atau staf panti yang mendukung aktivitas panti atau lembaga pengasuhan anak. Realitas administrasi ini memperlihatkan bahwa selama ini keberadaan panti atau lembaga pengasuhan anak yang ada di Kabupaten Sidoarjo sebagian besar masih belum didukung oleh kelengkapan administrasi khususnya terkait dengan nomor induk anak dan nomor induk petugas atau staf yang mendukung aktivitas panti/ lembaga pengasuhan anak. Meski secara administratif kebanyakan panti atau lembaga pengasuhan anak yang ditemui masih belum lengkap terutama terkait dengan nomor induk (anak maupun petugas) tetapi dalam hal keberadaan petugas khusus data base dan jadual kegiatan anak ternyata menunjukkan kondisi yang cukup baik. Menurut data yang ada sebanyak 72,09\% menyebutkan bahwa keberadaan panti telah dilengkapi dengan petugas khusus data base dan sejumlah $75,58 \%$ panti mengaku bahwa selama ini mereka memiliki jadual kegiatan untuk anak asuh yang tinggal di panti atau lembaga kesejahteraan sosial anak.

\section{Simpulan}

Panti pengasuhan anak yang banyak terdapat di Kabupaten Sidoarjo selama ini merupakan lembaga kesejahteraan sosial anak yang memberikan pelayanan terhadap anak-anak yang diharapkan mampu memberi dukungan bagi anak di dalam keluarga dengan orientasi utama penguatan kapasitas pengasuhan dalam keluarga. Persoalannya adalah apakah layanan yang diberikan oleh panti selama ini telah sesuai dengan standar nasional pengasuhan anak sebagaimana telah ditetapkan dalam Peraturan Menteri Sosial Republik Indonesia Nomor: 30/HUK/2011.

Berdasarkan hasil kajian yang dilakukan di berbagai Panti/ Lembaga Kesejahteraan Sosial Anak yang ada di Kabupaten Sidoarjo selanjutnya dapat dikemukakan beberapa temuan penting antara lain: Pertama, secara umum kondisi LKSA di Kabupaten Sidoarjo masih banyak yang belum memenuhi standarisasi yang telah ditetapkan dalam SNPA. Kendala yang dihadapi pengurus LKSA dalam memenuhi standarisasi SNPA, selain berkaitan dengan keterbatasan dana dan SDM, juga karena jumlah anak asuh yang dilayani tidak sebanding dengan kemampuan pendanaan dan SDM yang diimiliki. Kedua, bagi anak-anak asuh panti, situasi problematik yang mereka hadapi terkait dengan kondisi LKSA yang belum memadai adalah berusaha beradaptasi dengan situasi dan kondisi yang ada. 
Meski pun kondisi panti acapkali tidak sesuai dengan standarisasi yang telah ditetapkan, tetapi anakanak asuh yang ada umumnya tidak mempermasalahkan.

\section{Daftar Pustaka}

Ali Ridho (1986) Badan Hukum Dan Kedudukan Badan Hukum Perseroan, Perkumpulan, Koperasi, Yayasan, Wakaf. Bandung.

Fathul A (2015) Peran Panti Sosial Asuhan Anak (PSAA) "Harapan” Majeluk Mataram Dalam Meningkatkan Kreativitas Anak Terlantar. Mataram: Biro Penerbit Sekolah Tinggi Ilmu Administrasi. 16-17.

Irwanto MF \& Jeffry A (1999) Anak yang Membutuhkan Perlindungan Khusus di Indonesia: Analisis Situasi. Jakarta: Kerjasama PKPM Unika Atmajaya Jakarta, Departemen Sosial, dan UNICEF.

Kominfo (2011) Pedoman Oprasional Pendampingan: Pekerja Sosial Berhadapan dengan Hukum. Jakarta.

Mulia A (2013) Kebijakan Kesejahteraan dan Perlindungan Anak. Jakarta: P3KS Press.

Santrock JW (2007) Perkembangan Anak. Jakarta: Erlangga.

Supramono G (2005) Hukum Acara Pengadilan Anak. Jakarta: Djambatan.

Suyanto B (2013) Masalah Sosial Anak. Jakarta: Kencana Prenada Media Group. 226-227.

Suyanto B \& Sri SH (eds.) (2000) Pekerja Anak: Masalah dan Upaya Penanganannya. Surabaya: Kerjasama LPA Jatim dan UNICEF.

Suyanto B dkk (eds.) (2000) Tindak kekerasan Terhadap Anak: Masalah dan Upaya Pemantauannya. Surabaya: Kerjasama LPA Jatim dan UNICEF.

Suyanto B dkk (eds.) (2000) Child Abuse dan Anak yang Berkonflik Dengan Hukum. Surabaya: Kerjasama LPA Jatim, UNICEF dan POLDA Jatim.

Suyanto B \& Sri SH (2003) Krisis dan Child Abuse. Surabaya: Airlangga University Press.

Suyanto B (2003) Pelanggaran Hak dan Perlindungan Sosial Bagi Anak Rawan. Surabaya: Airlangga University Press.

Suyanto B (2012) Masalah Sosial Anak. Jakarta: Prenada Media Kencana.

Peraturan Menteri Sosial Republik Indonesia Nomor: 30/Huk/2011 Tentang Standar Nasional Pengasuhan untuk Lembaga Kesejahteraan Sosial Anak.

NN (2000) Challenges for a New Generation. The Situation of Children and Women in Indonesia 2000. UNICEF dan Pemerintah RI.

NN (2000) Pedoman Pembinaan Anak Terlantar. Dinas Sosial Propinsi Jawa Timur.

https://andibooks.wordpress.com/definisi-anak/ 